\title{
PERILAKU INVESTASI SEKTOR KEUANGAN \\ DI KALANGAN PEGAWAI NEGERI SIPIL : PENGEMBANGAN THEORY PLANNED OF BEHAVIOR
}

\author{
Sriatun dan Indarto ${ }^{1)}$ indarto@usm.ac.id \\ Program Studi Magister Manajemen Universitas Semarang
}

\section{Info Artikel}

Sejarah Artikel:

Diterima

Disetujui

Dipublikasikan

\section{Keywords:}

attitude toward the behaviour; subjective norms; perceived behavioral control; confirmation bias; investment intentions and investment decisions.

\begin{abstract}
Abstrak
Investasi sektor keuangan merupakan salah satu alternatif investasi yang cocok untuk Pegawai Negeri Sipil (PNS). Penelitian ini berusaha menganalisis faktor yang mempengaruhi minat berinvestasi serta menemukan faktor yang menyebabkan masih rendahnya tingkat investasi sektor ini di kalangan PNS dengan menggunakan dasar Theory Planned of Behavior dengan menambahkan faktor bias konfirmasi. Populasi penelitian adalah Pegawai Negeri Sipil yang bekerja pada Kantor Pelayanan Pajak di Semarang dengan jabatan Account Representative. Sampel penelitian sejumlah 120 yang penentuannya menggunakan simple random sampling. Data yang terkumpulkan dari hasil kuesioner dianalisis menggunakan Structural Equation Modeling (SEM) dengan menggunakan software amos ver.21.0.Hasil penelitian menunjukkan bahwa minat investasi dipengaruhi oleh sikap berperilaku, norma subjektif, kontrol perilaku, dan bias konfirmasi. Penelitian menemukan bahwa minat investasi tidak memediasi pengaruh sikap berperilaku, norma subjektif, kontrol perilaku, dan bias konfirmasi terhadap keputusan investasi. Temuan penelitan memperlihatkan bahwa keputusan investasi di kalangan PNS dipengaruhi oleh sikap berperilaku dan kontrol perilaku .
\end{abstract}

INVESMENT BEHAVIOR FINANCIAL SECTOR AMONG CIVIL SERVANTS : THEORY PLANNED OF BEHAVIOR DEVELOPMENT

\section{Abstract}

Investment finance sector is one of the alternative investments that are suitable for Civil Servants (PNS). This research seeks to analyze the factors that affect interest to invest and find the factors that led to the low level of investment this sector among civil servants using the basic Theory of Planned Behavior by adding a factor of confirmation bias. The study population is a Civil Servant who worked on the Tax Office in Semarang with positions Account Representative. The research sample number 120 that determination using simple random sampling. Data were collected from questionnaires were analyzed using Structural Equation Modeling (SEM) by using software amos ver.21.0. The results showed that the investment intentions are influenced by the attitude toward the behavior, subjective norms, perceived behavioral control, and confirmation bias. The study found that investment intentions are not mediating influence behaved attitude toward the behavior, subjective norms, perceived behavioral control, and confirmation bias towards investment decision. The findings of the research show that the investment decisions among civil servants behave is influenced by the attitude toward the behavior and perceived behavioral control.

\begin{tabular}{lr}
\hline Alamat korespondensi : & ISSN \\
Program Studi Magister Manajemen Universitas Semarang & 1979-480o (cetak) \\
E-mail: indarto@usm.ac.id & $2580-8451$ (online)
\end{tabular}




\section{PENDAHULUAN}

Indonesia merupakan salah satu negara dengan jumlah penduduk terbesar di dunia. Sesuai data sensus terakhir tahun 2010, dan asumsi pertumbuhan penduduk Indonesia yang dikeluarkan oleh Bank Dunia sebesar $1,21 \%$, perkiraan jumlah penduduk Indonesia 2016 adalah 256,5 juta jiwa, terbesar keempat di dunia setelah Cina/Tiongkok, India, dan Amerika Serikat. Besarnya jumlah penduduk bisa dipandang sebagai masalah atau sebaliknya sebagai aset, tergantung dari aspek mana memandangnya.

Sebagai aset, jumlah penduduk yang besar merupakan peluang untuk menambah jumlah masyarakat untuk berpartisipasi dalam pembangunan diantaranya melalui investasi baik secara langsung maupun melalui sektor keuangan. Data pada Neraca Pembayaran Indonesia tahun 2015, menunjukkan investasi secara langsung mencapai USD9,4 miliar turun dari tahun 2014 yang sebesar USD10,4 miliar. Sebagian besar berasal dari penanaman modal asing. Sementara itu, surplus investasi portofolio neto turun menjadi sekitar USD16,7 miliar dari USD26,1 miliar pada tahun 2014. Penurunan tersebut terutama disebabkan oleh menurunnya aliran masuk modal portofolio asing.

Peran investasi di sektor keuangan, saat ini juga semakin meluas ke bidang sarana dan prasarana (infrastruktur). Pemerintah ke depan akan lebih banyak menerbitkan surat berharga negara $(\mathrm{SBN})$ baik konvensional berupa obligasi maupun syariah (sukuk) dengan aset dasar (underlying asset) proyek atau project financing untuk menghindari bubble di sektor keuangan (Rahmat Waluyanto, Direktur Jenderal Pengelolaan Utang,

Tabel 1.1

Data Kepemilikan Efek Individu Lokal (Per Juni 2016)

\begin{tabular}{|l|c|r|}
\hline \multicolumn{1}{|c|}{ Keterangan } & $\begin{array}{c}\text { Sub Rekening } \\
\text { Efek }\end{array}$ & $\begin{array}{c}\text { Single Investor } \\
\text { Identity }\end{array}$ \\
\hline Investor Individu-Lokal (PNS) yang memiliki aset & 15.070 & 13.907 \\
\hline Investor Individu-Lokal yang memiliki aset & 414.455 & 347.954 \\
\hline
\end{tabular}

Sumber : KSEI, data diolah

Kementerian Keuangan). Project financing tersebut digunakan untuk membiayai proyekproyek baru. Beberapa proyek pemerintah utamanya di bidang pembangunan sarana dan prasarana, saat ini dibiayai melalui obligasi. Oleh karena itu, investasi di sektor ini akan sangat membantu pembangunan perekonomian Indonesia secara keseluruhan. Karena itu ketersediaan sarana dan prasarana mutlak diperlukan guna meningkatkan geliat usaha di Indonesia. Selain itu, juga dalam rangka menutup pembiayaan dalam APBN.

Data pada PT Kustodian Sentral Efek Indonesia (KSEI) periode 30 Desember 2015, mencatat total kepemilikan efek mencapai Rp338.217.434.566.195,00 yang terdiri dari kepemilikan saham sebesar Rp2.412.736.925.632,00 dan non saham sebesar Rp335.804.697.640.563,00. Untuk kepemilikan non saham terdiri dari Corporate Bond, Government Bond, Warrant, Right, Medium Term Notes, Mutual Fund, SBSN, Sukuk, Eba,dan Dana Investasi Real Estate. Total Pegawai Negeri Sipil (PNS) seluruh Indonesia tahun 2014 sebanyak 4.455.303 orang. Di Jawa Tengah jumlahnya mencapai 451.310 (Badan Pusat Statistik, 2014). Data pada PT Kustodian Sentral Efek Indonesia, menunjukkan bahwa peran investor individu lokal (dalam negeri) dalam investasi pada sektor keuangan yang diukur dengan rupiah mencapai 15,3\% untuk saham dan sebesar 
9,67\% untuk non saham, sedangkan secara kuantitatif, jumlah individu lokal yang berinvestasi di sektor keuangan seperti pada tabel 1.2.

Masih rendahnya tingkat investasi sektor keuangan di kalangan masyarakat umumnya dan khususnya PNS diduga dipengaruhi oleh minat berinvestasi di sektor ini. Selain itu, faktor bias dan faktor eksternal diduga memegang peranan yang krusial dalam keputusan berinvestasi.

Penelitian keuangan yang dilakukan dengan menggunakan dasar Theory Planned of Behavior menghasilkan kesimpulan yang berbeda-beda di antara para peneliti. Demikan halnya hasil penelitian keuangan yang menggunakan faktor bias juga menghasilkan kesimpulan yang berbeda.

Tabel 1.2

Research Gap

\begin{tabular}{|c|c|c|}
\hline Research Gap & Isu/Peneliti & Temuan \\
\hline \multicolumn{3}{|l|}{ Gap 1: } \\
\hline \multirow{8}{*}{$\begin{array}{l}\text { Terdapat perbedaan hasil } \\
\text { penelitian mengenai pengaruh } \\
\text { sikap berperilaku terhadap } \\
\text { minat berinvestasi }\end{array}$} & $\begin{array}{l}\text { Isu : } \\
\text { Sikap berperilaku dan minat } \\
\text { berinvestasi }\end{array}$ & \\
\hline & $\begin{array}{l}\text { Ramadhan dan Hermanto } \\
(2015)\end{array}$ & $\begin{array}{l}\text { Sikap berpengaruh secara signifikan } \\
\text { terhadap minat investasi deposito }\end{array}$ \\
\hline & Tan dan Teo (2000) & $\begin{array}{l}\text { Sikap mempengaruhi minat } \\
\text { menggunakan layanan internet banking } \\
\text { untuk melakukan transaksi keuangan }\end{array}$ \\
\hline & Gopi dan Ramayah (2007) & $\begin{array}{l}\text { Sikap memiliki pengaruh yang positif } \\
\text { terhadap intensi penggunaan internet } \\
\text { dalam perdagangan saham oleh investor } \\
\text { di Malaysia. }\end{array}$ \\
\hline & East (1993) & $\begin{array}{l}\text { Perilaku individu dalam melakukan } \\
\text { investasi secara akurat dapat diprediksi } \\
\text { oleh intensi (minat) yang diukur dan } \\
\text { intensi tersebut dipengaruhi oleh sikap. }\end{array}$ \\
\hline & Alleyne dan Broome (2011) & $\begin{array}{l}\text { Sikap mempengaruhi secara signifikan } \\
\text { terhadap minat berinvestasi. }\end{array}$ \\
\hline & Hariady (2013) & $\begin{array}{l}\text { Sikap tidak mempengaruhi minat } \\
\text { berinvestasi }\end{array}$ \\
\hline & Rochmawati (2012) & $\begin{array}{l}\text { Sikap tidak berpengaruh terhadap niat } \\
\text { dalam penggunaan kartu kredit. }\end{array}$ \\
\hline \multicolumn{3}{|l|}{ Gap 2: } \\
\hline \multirow{5}{*}{$\begin{array}{l}\text { Terdapat perbedaan hasil } \\
\text { penelitian mengenai pengaruh } \\
\text { norma subjektif terhadap } \\
\text { minat berinvestasi }\end{array}$} & $\begin{array}{l}\text { Isu : } \\
\text { Norma subjektif dan minat } \\
\text { berinvestasi }\end{array}$ & \\
\hline & Septyanto (2013) & $\begin{array}{l}\text { Norma Subjektif berpengaruh terhadap } \\
\text { minat berinvestasi. }\end{array}$ \\
\hline & Rochmawati (2012) & $\begin{array}{l}\text { Norma subjektif mempengaruhi niat dalam } \\
\text { penggunaan kartu kredit. }\end{array}$ \\
\hline & Gopi dan Ramayah (2007) & $\begin{array}{l}\text { Norma subjektif memiliki pengaruh yang } \\
\text { positif terhadap intensi penggunaan } \\
\text { internet dalam perdagangan saham oleh } \\
\text { investor di Malaysia. }\end{array}$ \\
\hline & East (1993) & $\begin{array}{l}\text { Perilaku individu dalam melakukan } \\
\text { investasi secara akurat dapat diprediksi }\end{array}$ \\
\hline
\end{tabular}




\begin{tabular}{|c|c|c|}
\hline & & $\begin{array}{l}\text { oleh intensi (minat) yang diukur dan } \\
\text { intensi tersebut dipengaruhi norma } \\
\text { subjektif. }\end{array}$ \\
\hline & Alleyne dan Broome (2011) & $\begin{array}{l}\text { Norma subjektif mempengaruhi secara } \\
\text { signifikan terhadap minat berinvestasi. }\end{array}$ \\
\hline & Hariady (2013) & $\begin{array}{l}\text { Norma subjektif tidak mempengaruhi } \\
\text { minat berinvestasi }\end{array}$ \\
\hline & Tan dan Teo (2000) & $\begin{array}{l}\text { Norma subjektif tidak mempengaruhi } \\
\text { minat menggunakan layanan internet } \\
\text { banking untuk melakukan transaksi } \\
\text { keuangan }\end{array}$ \\
\hline & $\begin{array}{l}\text { Ramadhan dan Hermanto } \\
\text { (2015) }\end{array}$ & $\begin{array}{l}\text { Norma subyektif tidak berpengaruh } \\
\text { signifikan. terhadap minat investasi } \\
\text { deposito }\end{array}$ \\
\hline \multicolumn{3}{|l|}{ Gap 3 : } \\
\hline \multirow{7}{*}{$\begin{array}{l}\text { Terdapat perbedaan hasil } \\
\text { penelitian pengaruh kontrol } \\
\text { perilaku terhadap minat } \\
\text { berinvestasi }\end{array}$} & $\begin{array}{l}\text { Isu: } \\
\text { Kontrol perilaku dan minat } \\
\text { berinvestasi }\end{array}$ & \\
\hline & Hariady (2013) & $\begin{array}{l}\text { Kontrol keuangan mempengaruhi minat } \\
\text { berinvestasi }\end{array}$ \\
\hline & Tan dan Teo (2000) & $\begin{array}{l}\text { Kontrol Perilaku mempengaruhi minat } \\
\text { menggunakan layanan internet banking } \\
\text { untuk melakukan transaksi keuangan }\end{array}$ \\
\hline & Gopi dan Ramayah (2007) & $\begin{array}{l}\text { Kendali atas perilaku yang dirasakan } \\
\text { memiliki pengaruh yang positif terhadap } \\
\text { intensi penggunaan internet dalam } \\
\text { perdagangan saham oleh investor di } \\
\text { Malaysia. }\end{array}$ \\
\hline & East (1993) & $\begin{array}{l}\text { Perilaku individu dalam melakukan } \\
\text { investasi secara akurat dapat diprediksi } \\
\text { oleh intensi (minat) yang diukur dan } \\
\text { intensi tersebut dipengaruhi kendali yang } \\
\text { dipersepsikan. }\end{array}$ \\
\hline & Alleyne dan Broome (2011) & $\begin{array}{l}\text { Kontrol perilaku mempengaruhi secara } \\
\text { signifikan terhadap minat berinvestasi. }\end{array}$ \\
\hline & Rochmawati (2012) & $\begin{array}{l}\text { Kontrol perilaku tidak berpengaruh } \\
\text { terhadap niat dalam penggunaan kartu } \\
\text { kredit. }\end{array}$ \\
\hline \multicolumn{3}{|r|}{ 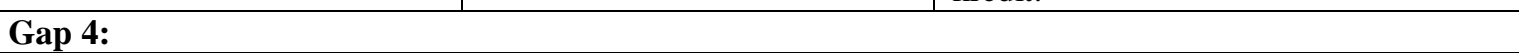 } \\
\hline \multirow{4}{*}{$\begin{array}{l}\text { Terdapat perbedaan hasil } \\
\text { penelitian mengenai penagaruh } \\
\text { bias terhadap keputusan } \\
\text { berinvestasi }\end{array}$} & $\begin{array}{l}\text { Isu : } \\
\text { Bias konfirmasi dan keputusan } \\
\text { berinvestasi }\end{array}$ & \\
\hline & Novia dan Rita (2014) & $\begin{array}{l}\text { Bias konfirmasi mempengaruhi } \\
\text { pengambilan keputusan keuangan }\end{array}$ \\
\hline & Chandra (2014) & $\begin{array}{l}\text { Terdapat hubungan yang signifikan } \\
\text { antara persepsi bias (overconfidence } \\
\text { bias, self control bias dan reliance on } \\
\text { expert bias) dengan keputusan investasi } \\
\text { (saham, reksadana, obligasi, emas, } \\
\text { properti, deposito, valuta asing) }\end{array}$ \\
\hline & Umairoh (2012) & $\begin{array}{l}\text { Cognitif dissonance bias tidak } \\
\text { berpengaruh terhadap pengambilan } \\
\text { keputusan investasi }\end{array}$ \\
\hline
\end{tabular}




\begin{tabular}{|l|l|l|}
\hline & Athalia (2012) & $\begin{array}{l}\text { Confirmation bias tidak berpengaruh } \\
\text { signifikan terhadap keputusan } \\
\text { pengambilan kredit pada pengusaha } \\
\text { makanan ringan }\end{array}$ \\
\hline
\end{tabular}

Sumber : Penelitian dan Jurnal, data diolah

Penelitian ini dilakukan untuk mengetahui dan menganalisis faktor apa yang menyebabkan masih rendahnya tingkat investasi sektor keuangan di kalangan Pegawai Negeri Sipil yang bekerja pada Kantor Pelayanan Pajak di Semarang. sehingga permasalahannya dapat dirumuskan sebagai berikut : Bagaimana cara meningkatkan investasi sektor keuangan di kalangan PNS.

\section{TELAAH PUSTAKA DAN PENGEMBANGAN HIPOTESIS}

\section{Pengertian Investasi}

Tandelilin (2001) menyatakan bahwa investasi merupakan komitmen atas sejumlah dana dan atas sumber daya lainnya yang dilakukan pada saat ini, dengan tujuan memperoleh sejumlah keuntungan di masa yang akan datang. Investasi dalam bentuk aset keuangan atau sektor keuangan dapat dilakukan baik di pasar uang maupun pasar modal, diintermediasi oleh perusahaan yang bergerak di industri keuangan, yaitu perusahaan efek yang dapat berfungsi sebagai penjamin emisi efek, perantara pedagang efek dan/atau manajer investasi dan lembaga perbankan yang berfungsi sebagai kustodian yaitu memberikan jasa penitipan efek dan harta lain yang berkaitan dengan efek, termasuk menerima deviden, bunga, dan hak-hak lain, menyelesaikan transaksi efek, dan mewakili pemegang rekening yang menjadi nasabahnya (Undang-Undang No. 8 tahun 1995).

\section{Teory Planned of Behavior}

Theory of Planned Behavior yang awalnya digunakan untuk menilai perilaku konsumen, dalam perkembangannya, telah diaplikasikan dalam berbagai macam konteks termasuk di bidang keuangan dan investasi. Teori itu intinya menyatakan bahwa minat seseorang melakukan sesuatu termasuk minat berinvestasi dipengaruhi sikap berperilaku, norma subjektif, dan kontrol perilaku. Minat berinvestasi akan menimbukan perilaku berupa keputusan investasi. Menurut teori ini, kontrol perilaku secara langsung dapat mempengaruhi keputusan investasi.

TPB diperkenalkan oleh Icek Ajzen, 1985, dalam artikel yang berjudul From Intention To Action: A Theory of Planned Behavior. Theory of Planned Behavior (TPB) merupakan pengembangan dari Theory of Reasoned Action (TRA). Dalam TRA dijelaskan bahwa niat seseorang terhadap perilaku dibentuk oleh dua faktor utama yaitu attitude toward the behavior dan subjective norms (Fishbein dan Ajzen, 1975), sedangkan dalam TPB ditambahkan satu faktor lagi yaitu perceived behavioral control (Ajzen,

1991).

Attitude toward the behavior (sikap berperilaku) merupakan kecenderungan yang dipelajari untuk memberikan respon kepada obyek atau kelas obyek secara konsisten baik dalam rasa suka maupun tidak suka. Sikap seseorang dalam menerima informasi mengenai investasi di sektor keuangan akan mempengaruhi perilakunya.

Subjective norm (norma subjektif) didefinisikan sebagai persepsi individu tentang pengaruh sosial dalam membentuk perilaku tertentu. (Ajzen, 1988). Subjective norm merupakan fungsi dari harapan yang dipersepsikan individu dimana satu atau lebih orang di sekitarnya (misalnya, saudara, teman kerja) menyetujui perilaku tertentu dan 
memotivasi individu tersebut untuk mematuhi mereka (Ajzen, 1991). Oleh karena itu, seorang individu akan cenderung melakukan perilaku jika termotivasi oleh lingkungan yang menyetujuinya.

Perceived behavioral control (kontrol perilaku) merupakan keadaan yang memudahkan atau menyulitkan seseorang untuk melakukan sesuatu. Kemudahan dapat diindikasikan sebagai ketersediaan faktor berupa dana, informasi, dan sarana prasarana untuk melakukan investasi di sektor keuangan. Sedangkan faktor kesulitan meliputi tidak adanya dana dan terbatasnya sarana serta akses informasi mengenai investasi di sektor keuangan. Kontrol perilaku adalah persepsi kemudahan atau kesulitan dalam melakukan suatu perilaku yang berkaitan dengan keyakinan tentang ketersediaan dukungan dan sumber daya atau hambatan untuk melakukan suatu perilaku (Lo Choi Tung, 2011).

\section{Bias Konfirmasi}

Menurut Shefrin (2007), aspek bias dibagi menjadi 4 jenis kategori yaitu: (1) excessive optimism, (2) overconfidence, (3) confirmation, dan (4) illusion of control. Confirmation bias juga diartikan sebagai tindakan mengabaikan informasi yang tidak mendukung pandangannya dan mengambil lebih banyak informasi yang sesuai. Penyimpangan konfirmasi tersebut terjadi karena adanya kesalahan sewaktu melakukan konfirmasi terhadap informasi yang didapatkan (Joutsen, 2009).

\section{Minat Investasi}

Menurut Salim dan Salim (1996) minat memiliki definisi sebagai kecenderungan hati yang tinggi terhadap sesuatu gairah, keinginan. Sedangkan investasi adalah sejumlah komitmen atas sejumlah dana atau sumber daya lainnya yang dilakukan pada saat ini, dengan tujuan memperoleh sejumlah keuntungan di masa yang akan datang (Tandelilin, 2001). Minat investasi merupakan kecenderungan individu terhadap suatu investasi yang didasari oleh pertimbangan akan memperoleh keuntungan di masa yang akan datang. Investasi memerlukan sumber daya lain dan diharapkan dalam jangka waktu tertentu memberikam return.

\section{Keputusan Investasi}

Keputusan berhubungan dengan aktivitas memilih dari sekian banyak alternatif yang ada yang didasari oleh pertimbangan tertentu (Supranto, 2003). Sedangkan Investasi adalah sejumlah komitmen atas sejumlah dana atau sumber daya lainnya yang dilakukan pada saat ini, dengan tujuan memperoleh sejumlah keuntungan di masa yang akan datang (Tandelilin, 2001). Sebuah keputusan investasi merupakan bentuk perilaku untuk memilih suatu investasi yang didasari oleh pertimbangan tertentu dan dilakukan dengan tujuan untuk mendapatkan keuntungan tertentu. Pertimbangan dalam pemilihan investasi bisa berasal dari dalam maupun luar individu yang bersangkutan.

\section{Hipotesis}

Penelitian ini mengadopsi Theory Planned of Behavior dari Azjen (1991) dengan variabel sikap berperilaku, norma subjektif, dan kontrol perilaku sebagai faktor yang mempengaruhi keputusan investasi melalui variabel intervening minat investasi dan menguji secara langsung pengaruh ketiga variabel terhadap keputusan investasi. Variabel bias konfirmasi ditambahkan sebagai faktor yang diduga dapat mempengaruhi minat dan keputusan investasi sebagai pengembangan penelitian Chandra (2014). Terdapat delapan hipotesis yang akan diuji pada penelitian ini; (1) H1 : Sikap berperilaku berpengaruh 
terhadap minat investasi; (2) $\mathrm{H} 2$ : Norma subjektif berpengaruh terhadap minat investasi; (3) H3 : Kontrol perilaku berpengaruh terhadap minat investasi; (4) H4 : Bias konfirmasi berpengaruh terhadap minat investasi;(5) H5: Minat berpengaruh terhadap keputusan investasi; (6) H6: Sikap berperilaku berpengaruh terhadap keputusan investasi; (7) H7 : Norma subjektif berpengaruh terhadap keputusan investasi dan (8) H8 : Kontrol perilaku berpengaruh terhadap keputusan investasi.

H9 : Bias konfirmasi berpengaruh terhadap keputusan investasi.

\section{METODOLOGI PENELITAN}

\section{Jenis dan Variabel Penelitian}

Penelitian akan dilakukan untuk mengetahui dan menganalisis faktor-faktor yang mempengaruhi minat dan keputusan PNS untuk berinvestasi di sektor keuangan dengan menggunakan dasar Theory Planned of Behavior, dengan menambahkan faktor lain yaitu bias konfirmasi. Data yang digunakan adalah data primer yang diperoleh melalui kuesioner.

Penelitian ini menggunakan enam konstruk yang terdiri dari dua konstruk endogen, yaitu minat investasi dan keputusan investasi serta empat konstruk exogen, yaitu sikap berperilaku, norma subjektif, kontrol perilaku, dan bias konfirmasi. Penelitian menggunakan satu variabel intervening atau variabel mediating yaitu minat investasi.

\section{Populasi dan Sampel}

Populasi dalam penelitian ini adalah Pegawai Negeri Sipil pada Direktorat Jenderal Pajak yang bekerja pada Kantor Pelayanan Pajak di Semarang dengan jabatan Account Representative. Penentuan sampel menggunakan simple random sampling, karena seluruh Account Representative memiliki kesempatan yang sama untuk dijadikan sampel. Penentuan jumlah sampel untuk analisis Structural Equation Modeling menggunakan rumus (Ferdinand, 2005): Jumlah sampel $=$ jumlah indikator $\mathrm{x} 5$ sampai 10. Penelitian akan menggunakan 24 indikator.

Selanjutnya Hair, dkk dalam Ferdinand (2005) menyatakan bahwa ukuran yang sampel sesuai untuk SEM adalah antara 100 - 200 sampel. Dengan mengacu pada pendapat Hair maka jumlah sampel yang digunakan dalam penelitian adalah 120 responden.

\section{Metode dan Skala Pengumpulan Data}

Penelitian menggunakan data primer yang diperoleh dari responden dengan menggunakan kuesioner yang mengungkap karakteristik responden, meliputi usia responden, lama bekerja, dan kantor tempat responden bekerja.

Tipe pertanyaan dalam kuesioner adalah pertanyaan tertutup dan terbuka. Pada pertanyaan tertutup, responden diminta untuk membuat pilihan diantara serangkaian alternatif yang diberikan oleh peneliti (Sekaran, 2006). Skala data jawaban responden atas pertanyaan penelitian dengan menggunakan Agree-Disagree Scale yang menghasilkan jawaban sangat tidak setuju - jawaban sangat setuju dalam rentang nilai 1 s.d. 10 (Ferdinand, 2006). 


\section{Metode Analisis}

Data yang terkumpulkan dari hasil kuesioner dianalisis menggunakan Structural Equation Modeling (SEM) atau model persamaan struktural dengan menggunakan software amos ver.21.0. Penelitian menggunakan dua konstruk endogen, empat konstruk exogen, dengan indikator sebanyak 24 , dengan model persamaan strukturalnya :

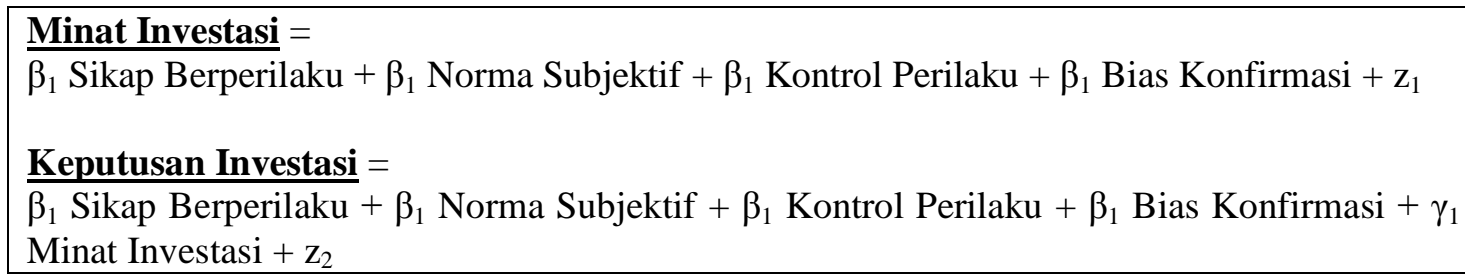

\section{Evaluasi Nilai Parameter}

Pengujian terhadap hipotesis dapat dilihat dari hasil koefisien standardized regression. Hipotesis diterima apabila hubungan antar konstruk signifikan. Reliabilitas merupakan ukuran konsistensi internal dari indikator-indikator sebuah variabel bentukan yang menunjukkan derajad sampai dimana masing-masing indikator itu mengindikasikan sebuah variabel bentukan yang umum. Terdapat dua cara yang dapat digunakan, yaitu composite (construct) reability dan variance extracted.

$$
\begin{aligned}
& \text { Construct Reliability }=\frac{\left(\sum \text { Std.Loading }\right)^{2}}{\left(\sum \text { Std.Loading }\right)^{2}+\sum \varepsilon j} \\
& \text { Variance Extracted }=\frac{\sum \text { Std.Loading }{ }^{2}}{\sum \text { Std.Loading }{ }^{2}+\sum \varepsilon j}
\end{aligned}
$$

Dimana:

- $\quad$ Std. Loading diperoleh langsung dari standardized loading untuk tiap-tiap indikator (diambil dari perhitungan komputer).

- $\quad$ ej adalah measurement error dari tiap indikator

Cut-off value dari construct reliability adalah minimal 0,70. Sedangkan cut-off value untuk variance extracted minimal 0,50 yang mencerminkan bahwa faktor yang dianalisis secara bersama-sama mampu menunjukkan adanya sebuah unidimensionalitas.

\section{Evaluasi Asumsi SEM}

a. Normalitas

Normalitas merupakan bentuk distribusi data pada suatu variabel matriks tunggal untuk menghasilkan distribusi normal (Sarjono dan Julianita, 2015). Normalitas data terpenuhi apabila distribusi data mampu membentuk distribusi normal. Evaluasi asumsi dilakukan melalui uji normalitas, dilakukan dengan menggunakan kriteria critical ratio skewness values sebesar +/- 2,58 pada tingkat signifikansi 0,01. Dapat disimpulkan normal jika nilai critical ratio skewness values dibawah harga mutlak 2,58 (Ghozali, 2004). 


\section{b. Evaluasi Outlier}

Outlier adalah kondisi observasi dari suatu data yang memiliki karekteristik unik yang terlihat sangat jauh berbeda dari observasi-observasi lainnya dan muncul dalam bentuk nilai ekstrim, baik untuk sebuah variabel tunggal maupun variabel-variabel kombinasi (Ghozali, 2004 : 227). Deteksi terhadap multivariate outliers dilakukan dengan memperhatikan nilai mahalanobis distance. Kriteria yang digunakan adalah berdasarkan nilai Chi-squares pada derajat kebebasan (degree of freedom) 23 yaitu jumlah variabel indikator pada tingkat signifikansi $\mathrm{p}<0,001$. Nilai mahalanobis distance $\mathrm{X}^{2}(23,0.001)=49,728$. Hal ini berarti semua kasus yang memiliki mahalanobis distance yang lebih besar dari 49,728 adalah multivariate outliers.

\section{c. Evaluasi Multikolinearitas}

Multikolinieritas dapat dilihat melalui determinan matriks kovarians. Nilai determinan yang sangat kecil menunjukkan indikasi terdapatnya masalah multikolinieritas atau singularitas sehingga data tidak dapat digunakan untuk penelitian (Ghozali, 2004). Asumsi multikolinearitas mensyaratkan tidak adanya korelasi yang sempurna atau besar di antara variabel-variabel exogen. Nilai korelasi di antara variabel yang teramati tidak boleh sebesar 0,9 atau lebih (Sarjono dan Julianita, 2015).

\section{d. Evaluasi Nilai Residual}

Setelah melakukan estimasi, residualnya haruslah kecil atau mendekati nol dan distribusi frekuensi dari kovarians residual haruslah bersifat simetrik. Jika suatu model memiliki nilai kovarians residual yang tinggi $(>2,58)$ maka sebuah modifikasi perlu dipertimbangkan dengan catatan ada landasan teoritisnya.

\section{e. Kecocokan Keseluruhan Model}

Pengujian keseluruhan model dilakukan melalui uji chi-square $\left(\mathrm{X}^{2}\right)$. Pengujian dilakukan untuk mengevaluasi fit-nya model secara keseluruhan dan menilai besarnya perbedaan antara sampel dan matrik kovarians (Sarjono dan Julianita, 2015). Model dikatakan fit sempurna jika nilai chi-square-nya sama dengan nol.

\section{HASIL PENELITIAN}

\section{Profil Responen}

Responden dalam penelitian ini adalah Pegawai Negeri Sipil pada Kantor Pelayanan Pajak di Semarang dengan jabatan Account Representative. Usia responden sebagian besar berkisar antara 29 sampai sampai dengan 36 tahun yang mencapai 24\%. Masa kerja responden didominasi pada tingkat 15 sampai dengan 18 tahun sebesar $27 \%$ dari keseluruhan responden. Sebagian besar responden $46 \%$ tidak memiliki investasi dalam bentuk apapun. Investasi sektor keuangan yang banyak dimiliki responden adalah unit link sebsar $19 \%$. Sementara itu investasi pada saham, obligasi, sukuk, dan reksadana jumlahnya masih relatif kecil. Sementara itu, dilihat dari asal kantor tempat kerja responden jumlahnya berimbang, paling banyak berasal dari KPP Madya Semarang yang mencapai $17 \%$ dan paling sedikit berasal dari KPP Pratama Semarang Tengah I yaitu sebesar $11 \%$. 


\section{Analisis Deskriptif}

Deskripsi variabel penelitian dilakukan untuk mendapatkan gambaran jawaban responden mengenai variabel-variabel yang diteliti dalam penelitian ini yang dilakukan dengan menggunakan teknik analisis Indeks. Adapun hasil perhitungan nilai indeks untuk masing-masing variabel penelitian diuraikan di bawah ini.

Tabel 4.1

Deskripsi Indeks Jawaban

\begin{tabular}{|c|l|c|c|c|}
\hline No & Diskripsi Jawaban & Nilai Indeks & Indikator Teringgi & $\begin{array}{c}\text { Indikator } \\
\text { Terendah }\end{array}$ \\
\hline 1. & Sikap berperilaku & 66,8 & $\mathrm{X} 3$ & $\mathrm{X} 1$ \\
\hline 2. & Norma subjektif & 69,1 & $\mathrm{X} 7$ & $\mathrm{X} 8$ \\
\hline 3. & Kontrol perilaku & 56,4 & $\mathrm{X} 9$ & $\mathrm{X} 11$ \\
\hline 4. & Bias konfirmasi & 55,7 & $\mathrm{X} 14$ & $\mathrm{X} 13$ \\
\hline 5. & Minat investasi & 53,6 & $\mathrm{X} 22$ & $\mathrm{X} 19$ \\
\hline 6. & Keputusan investasi & 69,7 & $\mathrm{X} 23$ \\
\hline
\end{tabular}

Berdasarkan tabel tersebut menunjukkan bahwa kecenderungan sikap berperilaku, norma subjektif, kontrol perilaku, bias konfirmasi, minat investasi, dan keputusan investasi responden berada dalam kategori sedang.

\section{Analisis Konfirmatori}

Analisis faktor konfirmatori merupakan tahap pengukuran terhadap indikatorindikator yang membentuk variabel laten dalam model penelitian. Hasil analisis faktor konfirmatori dari masing-masing variabel dilakukan dengan menganalisis nilai standardized regression weight serta nilai variance extracted dan reliability construct. Berikut ini uraian analisis konfirmatori yang dilakukan dalam penelitian ini.

\section{A. Analisis Standardized Regression Weight}

Pengujian kemaknaan dari indikator-indikator yang membentuk variabel eksogen yang meliputi sikap berperilaku, norma subyektif, kontrol perilaku dan bias konfirmasi secara bersama-sama dianalisis dari nilai standardized regression weight pada masingmasing indikator. Jika diperoleh adanya nilai pengujian yang sangat signifikan maka hal ini mengindikasikan bahwa indikator tersebut cukup baik untuk membentuk membentuk variabel sikap berperilaku, norma subyektif, kontrol perilaku dan bias konfirmasi.

Tabel 4.2

Revisi Pengujian Kelayakan Variabel Eksogen

\begin{tabular}{|l|c|c|c|}
\hline $\begin{array}{c}\text { Goodness of Fit } \\
\text { Indeks }\end{array}$ & Cut off Value & Hasil & Evaluasi Model \\
\hline Chi-Square $(\mathrm{df}=98)$ & Kecil $(<122,108)$ & 108,355 & Baik \\
\hline Probability & $\geq 0,05$ & 0,223 & Baik \\
\hline CMIN/DF & $\leq 2,00$ & 1,106 & Baik \\
\hline GFI & $\geq 0,90$ & 0,901 & Baik \\
\hline AGFI & $\geq 0,90$ & 0,863 & Marginal \\
\hline TLI & $\geq 0,95$ & 0,975 & Baik \\
\hline CFI & $\geq 0,95$ & 0,979 & Baik \\
\hline RMSEA & $\leq 0,08$ & 0,030 & Baik \\
\hline
\end{tabular}

Sumber: Data primer yang diolah, 2017

Hasil pengujian kelayakan model yang disajikan pada Tabel 4.1 menunjukkan bahwa nilai Chi Square $=108,355$ dengan tingkat signifikansi sebesar 0,223 menunjukkan 
bahwa tidak terdapat perbedaan antara matriks kovarians sampel dengan matriks kovarians populasi yang diestimasi yang berarti model adalah fit.

Sementara itu, dari hasil analisis faktor konfirmatori pada variabel eksogen (sikap berperilaku, norma subyektif, kontrol perilaku dan bias konfirmasi) diperoleh bahwa nilai pengujian pada masing-masing faktor pembentuk suatu konstruk menunjukkan bahwa seluruh indikator telah memiliki nilai standardized regression weight $>0,5$ dan dengan signifikansi < 0,05. Dengan demikian pengukuran pada variabel eksogen (sikap berperilaku, norma subyektif, kontrol perilaku dan bias konfirmasi) akan dilakukan dengan menggunakan masing-masing empat indikator.

Pengujian kemaknaan dari indikator-indikator yang membentuk variabel endogen yang meliputi minat investasi dan keputusan investasi, dianalisis dari nilai standardized regression weight pada masing-masing indikator. Jika diperoleh adanya nilai pengujian yang sangat signifikan maka hal ini mengindikasikan bahwa indikator tersebut cukup baik untuk membentuk membentuk variabel minat investasi dan keputusan investasi. Hasil berikut merupakan pengujian kemaknaan masing-masing indikator dalam membentuk variabel minat investasi dan keputusan investasi.

Hasil pengujian kesesuaian model pada konfirmatori faktor analisis variabel minat investasi dan keputusan investasi disajikan dalam tabel berikut ini.

Tabel 4.3

Revisi Pengujian Kelayakan Variabel Endogen

\begin{tabular}{|l|c|c|c|}
\hline \multicolumn{1}{|c|}{ Goodness of Fit Indeks } & Cut off Value & Hasil & Evaluasi Model \\
\hline Chi-Square $(\mathrm{df}=19)$ & Kecil $(<30,143)$ & 22,264 & Baik \\
\hline Probability & $\geq 0,05$ & 0,271 & Baik \\
\hline CMIN/DF & $\leq 2,00$ & 1,172 & Baik \\
\hline GFI & $\geq 0,90$ & 0,954 & Baik \\
\hline AGFI & $\geq 0,90$ & 0,913 & Baik \\
\hline TLI & $\geq 0,95$ & 0,977 & Baik \\
\hline CFI & $\geq 0,95$ & 0,985 & Baik \\
\hline RMSEA & $\leq 0,08$ & 0,038 & Baik \\
\hline
\end{tabular}

Sumber: Data primer yang diolah, 2017

Hasil pengujian kelayakan model yang disajikan pada Tabel 4.25 menunjukkan bahwa nilai Chi Square = 22,264 dengan tingkat signifikansi sebesar 0,271 menunjukkan bahwa tidak terdapat perbedaan antara matriks kovarians sampel dengan matriks kovarians populasi yang diestimasi yang berarti model adalah fit.

Dari hasil analisis faktor konfirmatori pada variabel minat investasi dan keputusan investasi dapat diketahui bahwa terdapat nilai pengujian pada faktor pembentuk variabel keputusan investasi, yaitu X24 yang memiliki nilai standardized regression weight $<0,5$ dan dengan signifikansi $>0,05$, artinya indikator X24 tidak dapat menjadi pembentuk atau alat ukur variabel keputusan investasi. Dengan demikian pengukuran pada variabel minat investasi dilakukan dengan menggunakan empat indikator, yaitu X17-X20 dan variabel keputusan investasi diukur dengan menggunakan tiga indikator, yaitu X21-X23.

\section{B. Reliability Construct dan Variance Extracted}

Uji reliabilitas menunjukkan sejauh mana suatu alat ukur dapat memberikan hasil yang relatif sama apabila dilakukan pengukuran kembali pada obyek yang sama. Nilai reliabilitas minimum dan dimensi/indikator pembentuk variabel laten yang dapat diterima 
adalah sebesar 0,70. Sedangkan pengukuran Variance Extract menunjukkan jumlah varians dari indikator yang diekstraksi oleh konstruk/variabel laten yang dikembangkan. Nilai Variance Extract yang dapat diterima adalah minimal 0,50. Hasil perhitungan Reliability Construct dan Variance Extracted dapat dilihat pada Tabel 4.6.

Tabel 4.4

Reliability Construct dan Variance Extracted

\begin{tabular}{|l|c|c|}
\hline \multicolumn{1}{|c|}{ Variabel } & Reliabilitas & Variance \\
\hline Sikap Berperilaku & 0,955 & 0,843 \\
\hline Norma Subjektif & 0,943 & 0,807 \\
\hline Kontrol Perilaku & 0,952 & 0,833 \\
\hline Bias Konfirmasi & 0,935 & 0,784 \\
\hline Minat Investasi & 0,944 & 0,808 \\
\hline Keputusan Investasi & 0,919 & 0,792 \\
\hline
\end{tabular}

Sumber: Data Primer yang Diolah, 2017

Berdasarkan hasil perhitungan yang ditampilkan dalam Tabel 4.6 diketahui bahwa seluruh variabel laten dapat memenuhi kriteria Reliability Construct dan Variance Extract. Sehingga dapat disimpulkan bahwa indikator-indikator yang diamati dapat mencerminkan faktor yang dianalisis dan secara bersama-sama mampu mencerminkan adanya sebuah unidimensionalitas.

\section{Pengujian Asumsi SEM \\ a. Evaluasi Normalitas Data}

Estimasi dengan Maximum Likelihood menghendaki variable observed harus memenuhi asumsi normalitas multivariate. Analisa normalitas dilakukan dengan mengamati nilai CR untuk multivariate dengan rentang $\pm 2,58$ pada tingkat signifikansi $1 \%$ (Ghozali, 2004).

Hasil pengujian normalitas menunjukkan bahwa nilai CR untuk multivariate adalah 0,589 yang berada di bawah 2,58, sehingga dapat dikatakan tidak terdapat bukti bahwa distribusi data variable observed tidak normal.

\section{b. Evaluasi Outliers}

Outliers adalah observasi atau data yang memiliki karakteristik unik yang terlihat sangat berbeda dengan data lainnya dan muncul dalam bentuk nilai ekstrim, baik untuk variabel tunggal maupun kombinasi (Hair, et al, 1995, p.57). Evaluasi atas outliers multivariate dijelaskan di bawah ini.

Uji Jarak Mahalanobis (Mahalanobis Distance) digunakan untuk melihat ada tidaknya outliers secara multivariate. Untuk menghitung Mahalanobis Distance berdasarkan nilai Chi-Square pada derajat bebas 23 (jumlah indikator) pada tingkat $\mathrm{p}<$ 0,001 adalah $\chi^{2}(23 ; 0,001)=49,728$ (berdasarkan tabel distribusi $\left.\chi^{2}\right)$. Berdasarkan hasil pengolahan data dapat diketahui bahwa jarak Mahalanobis maksimal adalah 40,139 yang lebih kecil dari $\chi^{2}$ tabel $(49,728)$ yang berarti bahwa tidak terdapat multivariate outliers sehingga dapat disimpulkan bahwa tidak terdapat masalah outliers pada data penelitian

\section{c. Evaluasi Multicollinearity dan Singularity}

Pengujian data selanjutnya adalah untuk melihat apakah terdapat multikolinieritas dalam sebuah kombinasi variabel eksogen. Indikasi adanya multikolinieritas dan 
singularitas dapat diketahui melalui nilai determinan matriks kovarians yang benar-benar kecil atau mendekati nol. Dari hasil pengolahan data, nilai determinan matriks kovarians sample adalah: Determinant of sample covariance matrix $=27260401189908,800$

Dari hasil pengolahan data tersebut dapat diketahui nilai determinant of sample covariance matrix berada jauh dari nol. Sehingga dapat disimpulkan bahwa data penelitian yang digunakan tidak terdapat multikolinieritas.

\section{d. Evaluasi Nilai Residual}

Setelah melakukan estimasi, residualnya haruslah kecil atau mendekati nol dan distribusi frekuensi dari kovarians residual haruslah bersifat simetrik. Jika suatu model memiliki nilai kovarians residual yang tinggi $(>2,58)$ maka sebuah modifikasi perlu dipertimbangkan dengan catatan ada landasan teoritisnya. Dari hasil analisis statistik yang dilakukan dalam penelitian ini, tidak ditemukan satu nilai standardized residual kovarians yang lebih dari 2,58 sehingga dapat disimpulkan bahwa syarat residual terpenuhi (hasil terlampir).

\section{e. Pengujian Kelayakan Model Penelitian}

Setelah dilakukan analisis terhadap tingkat unidimensionalitas dari dimensidimensi/indikator-indikator pembentuk variabel laten yang diuji dengan confirmatory factor analysis, analisis selanjutnya adalah analisis Structural Equal Modeling (SEM) secara full model. Tahap pertama dalam pengujian model penelitian adalah melakukan analisis kelayakan model penelitian. Adapun hasil pengujian kelayakan pada model penelitian yang dikembangkan dalam penelitian ini, disajikan dalam Tabel 4.13 berikut ini.

Tabel 4.5

\section{Hasil Pengujian Kelayakan Model Penelitian}

\begin{tabular}{|l|c|c|c|}
\hline \multicolumn{1}{|c|}{ Goodness of Fit Indeks } & Cut off Value & Hasil & Evaluasi Model \\
\hline Chi-Square $(\mathrm{df}=215)$ & $<250,207$ & 221,094 & Baik \\
\hline Probability & $\geq 0,05$ & 0,373 & Baik \\
\hline CMIN/DF & $\leq 2,00$ & 1,028 & Baik \\
\hline GFI & $\geq 0,90$ & 0,867 & Marginal \\
\hline AGFI & $\geq 0,90$ & 0,829 & Marginal \\
\hline TLI & $\geq 0,95$ & 0,991 & Baik \\
\hline CFI & $\geq 0,95$ & 0,992 & Baik \\
\hline RMSEA & $\leq 0,08$ & 0,015 & Baik \\
\hline
\end{tabular}

Sumber: Data primer yang diolah, 2017

Berdasarkan hasil pengujian kelayakan model yang disajikan dalam Tabel 4.29 di atas menunjukkan bahwa secara keseluruhan kriteria pengujian dalam kategori baik atau memenuhi kriteria penilaian yang dipersyaratkan. Model penelitian ini menunjukkan bahwa nilai Chi-Square hitung adalah 221,094, sedangkan nilai kritis/tabel Chi-Square dengan $\mathrm{df}=215$ adalah 250,207. Oleh karena nilai Chi-Square hitung dalam penelitian ini lebih kecil dari nilai kritis/tabelnya ini berarti bahwa model penelitian ini tidak berbeda dengan populasi yang diestimasi/model dianggap baik (diterima). 


\section{f. Pengujian Hipotesis dan Pembahasan}

Setelah melakukan penilaian terhadap asumsi-asumsi yang ada pada SEM, selanjutnya akan dilakukan pengujian hipotesis sebagaimana diajukan pada bab terdahulu. Pengujian kesembilan hipotesis yang diajukan dalam penelitian ini dilakukan dengan menganalisis nilai Critical Ratio (CR) dan probabilitas dari suatu hubungan kausalitas.

Tabel 4.

Pengujian Hipotesis

\begin{tabular}{|c|c|c|c|c|c|c|c|}
\hline & & & $\begin{array}{c}\text { Std } \\
\text { Estimate }\end{array}$ & Estimate & S.E. & C.R. & $\mathrm{P}$ \\
\hline Minat_Investasi & $<---$ & Sikap_Berperilaku & ,318 & ,331 & ,114 & 2,910 & ,004 \\
\hline Minat_Investasi & $<---$ & Norma_Subjektif & 231 & 287 & 139 & 2,061 & 039 \\
\hline Minat_Investasi & $<---$ & Kontrol_Perilaku & ,464 & ,460 & , 129 & 3,582 & $* * *$ \\
\hline Minat_Investasi & $<---$ & Bias_Konfirmasi & ,272 & ,318 & 144 & 2,205 & 027 \\
\hline Keputusan_Investasi & $<---$ & Sikap_Berperilaku & ,275 & ,270 & ,133 & 2,024 & ,043 \\
\hline Keputusan_Investasi & $<---$ & Norma_Subjektif &,- 094 &,- 110 & 146 &,- 756 & , 450 \\
\hline Keputusan_Investasi & $<---$ & Kontrol_Perilaku & ,438 & ,409 & 165 & 2,476 & ,013 \\
\hline Keputusan_Investasi & $<---$ & Bias_Konfirmasi &,- 073 &,- 080 & ,152 &,- 528 & ,598 \\
\hline Keputusan_Investasi & $<---$ & Minat_Investasi & ,457 & ,430 & 202 & 2,127 & ,033 \\
\hline
\end{tabular}

Sumber: Data primer yang diolah, 2017

\section{Pengujian Pengaruh Sikap Berperilaku terhadap Minat Investasi}

Parameter estimasi untuk pengujian pengaruh sikap berperilaku terhadap minat investasi menunjukkan nilai CR sebesar 2,910 dengan probabilitas sebesar 0,004. Oleh karena nilai probabilitas $<0,05$ maka dapat disimpulkan bahwa variabel sikap berperilaku terbukti secara signifikan berpengaruh positif terhadap minat investasi (H1 : diterima).

Keyakinan bahwa investasi mampu meningkatkan nilai asset didukung pemilihan jenis investasi yang tepat serta lembaga keuangan yang terpercaya. Secara umum responden menyatakan keyakinannya bahwa investasi mampu memenuhi kebutuhan di masa yang akan datang dengan syarat tepat dalam memilih investasi serta adanya lembaga yang mengawasi dan menjamin keamanan asset keuangannya.

Sikap berperilaku berpengaruh positif secara signifikan terhadap minat investasi. Hasil penelitian ini mendukung Theory Planned of Behavior dan hasil penelitian yang dilakukan oleh Ramadhan dan Hermanto (2015), Alleyne dan Broome (2011), Tan dan Teo (2000), Gopi dan Ramayah (2007, dan penelitian East (1993). Hasil penelitian ini bertolak belakang dengan penelitian yang dilakukan oleh Hariady (2013) dan Rochmawati (2012).

\section{Pengujian Pengaruh Norma Subjektif terhadap Minat Investasi}

Parameter estimasi untuk pengujian pengaruh norma subjektif terhadap minat investasi menunjukkan nilai CR sebesar 2,061 dengan probabilitas sebesar 0,039. Oleh karena nilai probabilitas $<0,05$ maka dapat disimpulkan bahwa variabel norma subyektif terbukti secara signifikan berpengaruh positif terhadap minat investasi ( $\mathrm{H} 2$ : diterima).

Keputusan untuk melakukan investasi lebih dipengaruhi adanya kebutuhan yang harus dipenuhi di masa yang akan datang bukan pengaruh tuntutan gaya hidup. Minat investasi juga dipengaruhi paling dominan oleh orang lain yang kompeten. Kemudian diikuti oleh pengaruh anggota keluarga dan teman. Lingkungan keluarga dan lingkungan kerja dalam hal ini teman kerja mempengaruhi minat investasi sektor keuangan di kalangan PNS. 
Norma Subjektif berpengaruh positif secara signifikan terhadap minat investasi. Hasil penelitian ini mendukung Theory Planned of Behavior dan hasil penelitian terdahulu yang dilakukan oleh Septyanto (2013), Rochmawati (2012), Alleyne dan Broome (2011), Gopi dan Ramayah (2007) dan East (1993). Hasil penelitian ini bertolak belakang dengan hasil penelitian yang dilakukan oleh Hariady (2013), Tan dan Teo (2000), serta penelitian Ramadhan dan Hermanto (2015).

\section{Pengujian Pengaruh Kontrol Perilaku terhadap Minat Investasi}

Parameter estimasi untuk pengujian pengaruh kontrol perilaku terhadap minat investasi menunjukkan nilai CR sebesar 3,582 dengan probabilitas sebesar 0,000. Oleh karena nilai probabilitas $<0,05$ maka dapat disimpulkan bahwa variabel kontrol perilaku terbukti secara signifikan berpengaruh positif terhadap minat investasi ( $\mathrm{H} 3$ : diterima).

Kemudahan melakukan investasi dan kemudahan untuk mencari informasi mengenai cara berinvestasi di sektor keuangan akan meningkatkan minat Pegawai Negeri Sipil untuk berinvestasi di sektor keuangan. Sebenarnya, informasi untuk melakukan investasi pada sektor ini sudah tersedia. Namun, responden belum mengetahuinya dan memahaminya. Oleh karena itu, diperlukan tindakan langsung dari pemerintah (dalam hal ini Otoritas Jasa Keuangan) dan lembaga keuangan (dalam hal ini perusahaan sekuritas) untuk secara langsung memberikan pemahaman kepada para PNS.

Kontrol perilaku berpengaruh positif secara signifikan terhadap minat investasi. Hasil penelitian ini mendukung Theory Planned of Behavior dan hasil penelitian Hariady (2013), East (1993), Alleyne dan Broome (2011, Tan dan Teo (2000), serta penelitian Gopi dan Ramayah (2007), namun bertolak belakang dengan penelitian yang dilakukan oleh Rochmawati (2012).

\section{Pengujian Pengaruh Bias Konfirmasi terhadap Minat Investasi}

Parameter estimasi untuk pengujian pengaruh bias konfirmasi terhadap minat investasi menunjukkan nilai CR sebesar 2,205 dengan probabilitas sebesar 0,027. Oleh karena nilai probabilitas $<0,05$ maka dapat disimpulkan bahwa variabel bias konfirmasi terbukti secara signifikan berpengaruh positif terhadap minat investasi ( $\mathrm{H} 4$ : diterima).

Bias konfirmasi terbukti mempengaruhi minat investasi, terutama jika informasi tersebut disampaikan oleh orang yang kompeten di bidangnya dan sesuai dengan pendapatnya. Sebaliknya, kecenderungan untuk mengesampingkan informasi yang berkaitan dengan investasi serta kecenderungan untuk mengesampingkan pendapat orang yang bertentangan dengan pemikiran sendiri dapat menurunkan minat investasi utamanya di sektor keuangan.

Bias konfirmasi berpengaruh positif secara signifikan terhadap minat investasi. Hasil penelitian ini memperlihatkan bahwa faktor bias yang dapat mempengaruhi minat investasi di sektor keuangan. Hasil penelitian ini mendukung hasil penelitian Sumani dan Sandroto (2012) serta Phan dan Zhou (2014).

\section{Pengujian Pengaruh Minat Investasi terhadap Keputusan Investasi}

Parameter estimasi untuk pengujian pengaruh minat investasi terhadap keputusan investasi menunjukkan nilai CR sebesar 2,127 dengan probabilitas sebesar 0,033. Oleh karena nilai probabilitas < 0,05 maka dapat disimpulkan bahwa variabel minat investasi secara statistik terbukti berpengaruh signifikan terhadap keputusan investasi (H5 : diterima)

Perilaku untuk mengambil suatu investasi dapat diukur dengan seberapa besarnya keinginan untuk segera berinvestasi, memiliki rasa ketertarikan terhadap investasi, 
intensitas pencarian informasi yang berkaitan dengan investasi serta adanya keinginan preferensial terhadap investasi tertentu.

Minat investasi berpengaruh positif secara signifikan terhadap keputusan investasi. Hasil penelitian ini mendukung Theory Planned of Behavior dan hasil penelitian yang dilakukan oleh Ramadhan dan Hermanto (2015) dan East (1993). Namun bertolak belakang dengan hasil penelitian Handayani (2005) dan Wiyono (2008).

\section{Pengujian Pengaruh Sikap Berperilaku terhadap Keputusan Investasi}

Parameter estimasi untuk pengujian pengaruh sikap berperilaku terhadap keputusan investasi menunjukkan nilai CR sebesar 2,024 dengan probabilitas sebesar 0,043. Oleh karena nilai probabilitas $<0,05$ maka dapat disimpulkan bahwa variabel sikap berperilaku terbukti secara signifikan berpengaruh positif terhadap keputusan investasi (H6 : diterima).

Keyakinan bahwa investasi mampu meningkatkan nilai asset dan dapat memenuhi kebutuhan di masa yang akan datang menyebabkan timbulnya perilaku pengambilan keputusan berinvestasi. Selain itu, keyakinan bahwa investasi dapat menghasilkan return serta keyakinan terhadap investasi sebagai salah satu bentuk perencanaan keuangan yang tepat juga akan mempengaruhi keputusan individu dalam berinvestasi. Masih relatif sedikitnya jumlah PNS yang berinvestasi pada sektor ini lebih disebabkan oleh ketidakpahaman dan anggapan bahwa investasi di sektor keuangan rumit dan berisiko.

Sikap berperilaku berpengaruh positif secara signifikan terhadap keputusan investasi. Hasil penelitian ini menemukan bahwa sikap berperilaku dapat mempengaruhi keputusan investasi tanpa dimediasi oleh variabel minat investasi. Hasil penelitian ini mendukung penelitian terdahulu oleh Aminatuzzahra' (2014).

\section{Pengujian Pengaruh Norma Subjektif terhadap Keputusan Investasi}

Parameter estimasi untuk pengujian pengaruh norma subjektif terhadap keputusan investasi menunjukkan nilai CR sebesar -0,756 dengan probabilitas sebesar 0,450. Oleh karena nilai probabilitas $>0,05$ maka dapat disimpulkan bahwa variabel norma subyektif terbukti tidak berpengaruh signifikan terhadap keputusan investasi (H7 : Ditolak).

Berkaitan dengan investasi, lingkungan sosial seperti teman, saudara, dan keluarga akan dapat mempengaruhi keputusan investasi yang akan diambilnya. Analisis secara statistik menunjukkan bahwa norma subjektif tidak berpengaruh signifikan terhadap keputusan investasi mempunyai makna bahwa responden cenderung bersikap rasional dalam pengambilan keputusan, pengaruh sosial orang lain, teman kerja, saudara, anggota keluarga dan lingkungan bukan pertimbangan utama dalam pengambilan keputusan investasi namun tergantung pada kemampuan dan keyakinan masing-masing individu. Norma subjektif tidak berpengaruh secara signifikan terhadap keputusan investasi. Hasil penelitian ini bertolak belakang dengan penelitian sebelumnya oleh Septyanto (2015).

\section{Pengujian Pengaruh Kontrol Perilaku terhadap Keputusan Investasi}

Parameter estimasi untuk pengujian pengaruh kontrol perilaku terhadap keputusan investasi menunjukkan nilai CR sebesar 2,476 dengan probabilitas sebesar 0,013 . Oleh karena nilai probabilitas $<0,05$ maka dapat disimpulkan bahwa variabel kontrol perilaku terbukti secara statistik berpengaruh signifikan terhadap keputusan investasi (H8 : Diterima). 
Ketidakpahaman apa dan bagaimana cara berinvestasi di sektor keuangan, anggapan bahwa berinvestasi di sektor keuangan rumit, tidak ada sarananya sarana pendukung serta anggapan bahwa investasi di sektor keuangan memerlukan dana yang besar merupakan alasan mengapa tingkat investasi di kalangan PNS pada sektor ini masih relatif rendah. Kontrol perilaku berpengaruh positif secara signifikan terhadap keputusan investasi. Hasil penelitian ini mendukung Theory Planned of Behavior dan hasil penelitian Mukhlison (2015).

\section{Pengujian Pengaruh Bias Konfirmasi terhadap Keputusan Investasi}

Parameter estimasi untuk pengujian pengaruh bias konfirmasi terhadap keputusan investasi menunjukkan nilai CR sebesar -0,528 dengan probabilitas sebesar 0,598. Oleh karena nilai probabilitas $>0,05$ maka dapat disimpulkan bahwa variabel bias konfirmasi terbukti tidak berpengaruh signifikan terhadap keputusan investasi (H9 : Ditolak).

Pendapat atau anggapan responden bahwa investasi di sektor keuangan itu rumit bukan faktor utama mengapa tidak mengambil investasi tersebut. Informasi yang masuk dapat dijadikan referensi namun keputusan investasi tetap tergantung pada pertimbangan dan keyakinan masing-masing individu.

Bias konfirmasi tidak berpengaruh secara signifikan terhadap keputusan investasi. Hasil penelitian ini mendukung hasil penelitian yang dilakukan oleh Umairoh (2012) dan Athalia (2012). Hasil penelitian ini bertolak belakang dengan penelitian Novia dan Rita (2014) serta Chandra (2014).

\section{Analisis Pengaruh Tidak Langsung}

Analisis pengaruh variabel intervening dilakukan untuk menguji signifikansi pengaruh sikap berperilaku, norma subjektif, kontrol perilaku dan bias konfirmasi terhadap keputusan investasi yang dimediasi oleh minat berinvestasi. Pengujian pengaruh variabel intervening dilakukan dengan menggunakan Sobel Test.

Uji Sobel ini dilakukan dengan cara menguji kekuatan pengaruh tidak langsung variabel independen (X) kepada variabel dependen (Y) melalui variabel mediasi (intervening) (M). Nilai t hitung ini dibandingkan dengan nilai t tabel. Jika nilai t hitung $>$ nilai t table.

Sesuai dengan analisis statistik dengan menggunakan sobel test, diketahui bahwa (a) Minat investasi secara statistik tidak terbukti memediasi pengaruh sikap berperilaku terhadap keputusan investasi;(b) Minat investasi secara statistik tidak terbukti memediasi pengaruh norma subjektif terhadap keputusan investasi; (c) Minat investasi secara statistik tidak terbukti memediasi pengaruh kontrol perilaku terhadap keputusan investasi;(d) Minat investasi secara statistik tidak terbukti memediasi pengaruh bias konfirmasi terhadap keputusan investasi. Hasil ini menunjukkan bahwa variabel minat investasi bukan merupakan variabel intervening bagi hubungan variabel sikap berperilaku, norma subjektif, kontrol perilaku, bias konfirmasi dengan variabel keputusan investasi. Keputusan investasi lebih kuat dipengaruhi secara langsung oleh variabel independen dalam hal ini variabel sikap berperilaku dan control perilaku. 


\section{Penutup}

Berdasarkan analisis dan pembahasan disimpulkan bahwa(1) Variabel sikap berperilaku, norma subjektif, kontrol perilaku, dan bias konfirmasi terbukti secara signifikan berpengaruh positif terhadap minat investasi. Semakin tinggi sikap berperilaku, norma subjektif, kontrol perilaku, dan bias konfirmasi, maka minat investasi sektor keuangan di kalangan PNS juga akan semakin tinggi; (2) Variabel minat investasi secara statistik terbukti berpengaruh signifikan terhadap keputusan investasi. Artinya semakin tinggi minat investasi sektor keuangan di kalangan PNS maka akan semakin tinggi tingkat investasi keuangan di kalangan PNS pada sektor tersebut; (3) Variabel sikap berperilaku terbukti secara signifikan berpengaruh positif terhadap keputusan investasi. Artinya, keputusan investasi sektor keuangan di kalangan PNS dipengaruhi oleh persepsi PNS terhadap investasi sektor keuangan. Semakin positif persepsi PNS mengenai investasi sektor keuangan, maka tingkat investasi sektor keuangan di kalangan PNS juga akan semakin tinggi; (4) Variabel norma subyektif terbukti tidak berpengaruh signifikan terhadap keputusan investasi. Artinya, keputusan investasi keuangan di kalangan PNS tidak dipengaruhi oleh tuntutan gaya hidup dan tidak dipengaruhi oleh anggota keluarga, teman, maupun orang lain;(5) Variabel kontrol perilaku terbukti secara signifikan berpengaruh positif terhadap keputusan investasi. Semakin tinggi tingkat kontrol perilaku maka tingkat investasi sektor keuangan di kalangan PNS akan semakin tinggi. Artinya keputusan investasi sektor keuangan di kalangan PNS dipengaruhi oleh faktor kemudahan dan pemahaman serta ketersediaan sumber daya dan dana; (6) Variabel bias konfirmasi terbukti tidak berpengaruh signifikan terhadap keputusan investasi. Artinya keputusan investasi sektor keuangan di kalangan PNS tidak dipengaruhi oleh pandangan PNS terhadap investasi keuangan.

Minat investasi berpengaruh terhadap keputusan investasi. Namun, hasil analisis hubungan tidak langsung memperlihatkan bahwa minat investasi tidak memediasi pengaruh sikap berperilaku, norma subjektif, kontrol perilaku, dan bias konfirmasi terhadap keputusan berinvestasi. Sehingga dapat disimpulkan bahwa keputusan investasi keuangan di kalangan PNS lebih kuat dipengarui secara langsung oleh variabel sikap berperilaku dan kontrol perilaku.

\section{Daftar Pustaka}

Augusty Ferdinand, 2006. Metode Penelitian Manajemen : Pedoman Penelitian untuk Skripsi, Tesis dan Disertasi Ilmu Manajemen, Semarang: Badan Penerbit Universitas Diponegoro

Christian Chandra 2014.Persepsi Bias Investor dalam Keputusan Investasi pada Masyarakat yang Berusia Produktif di Surabaya. FINESTA Vol.2, No.1, 109-113. Program Manajemen, Program Studi Manajemen Keuangan Fakultas Ekonomi, Universitas Kristen Petra, Surabaya. 
Eduardus Tandelilin, 2010. Portofolio dan Investasi, Yogyakarta: Kanisius

Eduardus Tandelilin, 2001.Analisis Investasi dan Manajemen Portofolio, Edisi Pertama. Yogyakarta: BPFE

Fishbein dan Ajzen, 1975, Theory of Reasone Action (TRA)

H.Shefrin, 2007.Behavioral Corporate Finance: Decesion that Create Value. McGrawHill/Irwin

Haryadi Sarjono dan Winda Julianita, 2015.Structural Equation Modelling (SEM): Sebuah Pengantar, Aplikasi untuk Penelitian Bisnis.Jakarta: Salemba Empat

Icek Ajzen, 1991, Theory of Planned Behavioral

Icek Ajzen, 1988, Attitudes, Personality and Behavior, Milton Keynes, Open University Press.

Icek Ajzen, 1987, Attitudes, Traits and Actions: Dispositional Prediction of Behavior in Personality and Social Psychology, in L.Berkowits (Ed), Advances in Experimental Social Psychology, 20, San Diego.CA.Academic Press, hal 1-63.

Icek Ajzen and M.Fishbein, (1980), Understanding Attitudes and Predicting Social Behavior, Englewood,NJ,Prentice Hall, Inc.

Imam Ghozali, 2004.Model Persamaan Struktural.Konsep \& Aplikasi Dengan Program AMOS 21,0 Badan Penerbit Universitas Diponegoro, Semarang.

Margaret Tan dan Thompson S.H.Teo,2000.Factors Influencing the Adption of zinternet Banking. Journal of The Assosiation for Information Systems Volume 1, Article 5 .

Pradiptaning Umairoh,2012.Cognitive Bias dan Emotional Bias dalam Pengambilan Keputusan Investasi Portofolio. Fakultas Ekonomika dan Bisnis. Universitas Kristen Satya Wacana, Salatiga.

Robert East, 1993.Investment Decesions and Theory of Planned Behavior.Journal of Economic Psychology 14. (1993) 337-375 North-Holland Kingston Polytechnic, Kingston, UK.

Salim HS dan Budi Sutrisno, 2008. Hukum Investasi di Indonesia.Penerbit PT Raja Grafindo Persada: Jakarta.

Sari Rochmawati, 2012. Pengaruh Sikap, Norma Subyektif, Kontrol Perilaku Persepsian, Persepsi Risiko, Persepsi Kebermanfaatan terhadap Niat Penggunaan Kartu Kredit.Fakultas Ekonomi dan Bisnis Universitas Brawijaya Malang. 
Uma Sekaran, 2006, Metodologi Penelitian untuk Bisnis, Edisi 4, Buku 1 dan 2, Jakarta, Salemba 4

Undang-Undang Nomor 5 Tahun 2014 Tentang Aparatur Sipil Negara

Undang - Undang Nomor 43 Tahun 1999 Tentang Perubahan Atas Undang-Undang Nomor 8 Tahun 1974 tentang Pokok-Pokok Kepegawaian

Undang-Undang Nomor 8 Tahun 1995 Tentang Pasar Modal

www.ksei.didownload 20 Mei 2016

www.sahabatinvestor.com 20 Februari 2016 